\title{
A (DES) CONSTRUÇÃO DO TIPO PENAL PREVISTO NO ARTIGO 89 DA LEI No. 8.666/93 PELA JURISPRUDÊNCIA - A EXIGÊNCIA DE COMPROVAÇÃO DO ELEMENTO SUBJETIVO ESPECIAL DO TIPO E O PREJUÍZO AO ERÁRIO PÚBLICO
}

\author{
THE (DES) CONSTRUCTION OF THE CRIMINAL TYPE PROVIDED FOR IN ARTICLE 89 OF \\ LAW N $N^{o} .8 .666 / 93$ FOR JURISPRUDENCE - THE REQUIREMENT TO PROVIDE THE \\ SPECIAL SUBJECTIVE ELEMENT OF THE TYPE AND THE DAMAGE TO THE PUBLIC \\ EXCHANGE
}

Jean Colbert Dias

Doutorando em Direito Empresarial e Cidadania pela Faculdade de Direito do Centro Universitário Curitiba - UNICURITIBA. Mestre em Direito Empresarial e Cidadania pela Faculdade de Direito do Centro Universitário Curitiba - UNICURITIBA. Professor Universitário. Advogado. E-mail: jean@diasferreiraadvogados.com.br

\section{Fernando Gustavo Knoerr}

Realizou estágio Pós- Doutoral na Universidade de Coimbra, Portugal. Doutor e Mestre em Direito do Estado Professor de Direito Administrativo da Escola da Magistratura do Paraná e da Fundação Escola do Ministério Público do Paraná / FEMPAR. É Professor Permanente do Programa de Mestrado em Direito Empresarial e Cidadania do UNICURITIBA. Ex-Procurador Federal. Ex-Juiz do TRE/PR. Advogado Sênior do Escritório Séllos-Knoerr Sociedade de Advogados. E-mail: fernando@sellosknoerr.com.br

Recebido em: 09/02/2020

Aprovado em: 23/04/2020

RESUMO: A pesquisa adota uma abordagem metodológica lógico-dialética, tendo por suporte a análise de referências bibliográficas, da legislação brasileira, em especial, da Lei no . 8.666/93 e as decisões judiciais proferidas pelo Supremo Tribunal e pelo Superior Tribunal de Justiça sobre o tema. $\mathrm{O}$ artigo busca parametrizar a concepção do legislador acerca da construção do tipo penal capitulado no artigo 89 da Lei $n^{\circ}$. 8.666/93, que na sua construção legislativa original e até hoje em vigor, prevê um crime meramente formal; bastando para sua configuração que o autor do fato promova a dispensa ou a inexigibilidade da licitação fora das hipóteses previstas em lei ou que deixe de observar as formalidades legais de praxe. A pesquisa também focou na investigação da atualíssima jurisprudência emanada dos Tribunais Superiores, para demonstrar que houve a edificação de um novo paradigma para caracterização do crime em tela. A pesquisa demonstrou que houve brusca alteração no norte jurisprudencial sobre o crime capitulado no art. 89 da Lei $\mathrm{n}^{\mathbf{0}}$. 8.666/93, que exige o preenchimento do elemento subjetivo especial do tipo e a constatação da ocorrência do prejuízo ao erário público no caso concreto, independentemente dessas previsões estarem ausentes do corpo da norma penal. O tema abordado neste estudo está impactando em casos judiciais em trâmite, culminado com muitas absolvições criminais, além da possibilidade da viabilização da propositura de ações de revisão criminal em face de condenações que assentaram- 
se na mera hipótese do crime formal, tendo em vista a (des) construção in bonam partem da norma penal objeto desta investigação.

Palavras-chave: Dispensa; Inexigibilidade; Licitação; Elemento Subjetivo Especial do Tipo; Dano ao Erário.

SUMMARY: The research adopts a logical-dialectical methodological approach, supported by the analysis of bibliographic references, of the Brazilian legislation, in particular, of Law n'. 8,666 / 93 and the judicial decisions handed down by the Supreme Court and the Superior Court of Justice on the subject. The article seeks to parameterize the legislator's conception about the construction of the penal type capitulated in article 89 of Law $n^{\circ} .8 .666 / 93$, which in its original legislative construction and still in force today, provides for a purely formal crime; it is enough for its configuration that the author of the fact promotes the waiver or unenforceability of the bidding outside the hypotheses provided by law or that fails to observe the usual legal formalities. The research also focused on investigating the very current jurisprudence emanating from the Superior Courts, to demonstrate that a new paradigm was built to characterize the crime on screen. The research showed that there was a sudden change in the north jurisprudence on the crime capitulated in art. 89 of Law $n^{\circ} .8 .666 / 93$, which requires filling in the special subjective element of the type and verifying the occurrence of damage to the public purse in the specific case, regardless of whether these forecasts are absent from the body of the criminal law. The topic addressed in this study is impacting on legal cases in progress, culminating in many criminal acquittals, in addition to the possibility of making criminal review actions feasible in the face of convictions that were based on the mere hypothesis of formal crime, in view of the (de) construction in bonam start from the penal norm object of this investigation.

Keywords: Dispensation; Unenforceability; Bidding; Special Subjective Element of Type; Damage to the Treasury.

SUMÁRIO: Introdução; 10 artigo 89 da lei de licitações e sua construção legislativa original; 2 A exigência de comprovação do elemento subjetivo especial do tipo; 3 A (des) construção do tipo penal previsto no artigo 89 da Lei $\mathrm{N}^{\circ}$. 8.666/93 pela jurisprudência; 4 A possibilidade de propositura da ação de revisão criminal diante do novo paradigma jurisprudencial in bonan partem; Considerações finais; Referências.

\section{INTRODUÇÃO}

Este artigo é fruto de pesquisa realizada acerca da opção do legislador por criminalizar, através do artigo 89 da Lei $n^{\circ} .8 .666 / 93^{1}$, a dispensa ou inexigibilidade de licitação, na circunstância que o servidor público legitimado a decidir por esse viés contratual, deixa de adotar o procedimento licitatório, quando deveria fazê-lo, ou singelamente deixa de observar as formalidades legais necessárias para não licitar.

As hipóteses de dispensa e inexigibilidade de licitação estão enumeradas na própria Lei de Licitações, em seus artigos 24 e 25, que complementam o tipo penal disposto no artigo 89, que é classificado pela doutrina como norma penal em branco homóloga.

\footnotetext{
${ }^{1}$ BRASIL. Lei no ${ }^{\circ}$ 8.666, de 21 de junho de 1993. Regulamenta o art. 37, inciso XXI, da Constituição Federal, institui normas para licitações e contratos da Administração Pública e dá outras providências. Disponível em: <http://www.planalto.gov.br/ccivil_03/leis/18666cons.htm>. Acesso em: 11 fev. de 2020.
} 
Quando o legislador idealizou a norma em voga, buscou definir o bem jurídico tutelado a partir do exame da política pública de moralidade prevista na Constituição Federal de $1988^{2}$, optando por criminalizar a conduta do servidor público e do extraneus, este exclusivamente na hipótese de infringência do tipo penal disposto no parágrafo único do artigo 89, quando houver laborado para impedir ou dificultar o tratamento isonômico dos concorrentes e a seleção da proposta mais vantajosa para a Administração Pública.

O legislador restringiu o elemento subjetivo do tipo à comprovação do agir doloso, consubstanciado na consciência e na vontade de violar o tipo penal em apreço, contudo, não se identifica nas elementares objetiva e subjetiva da norma a exigência de comprovação do elemento subjetivo especial do tipo, como por exemplo, o especial fim de agir.

$\mathrm{Na}$ doutrina há significativa divergência acerca da presença, somente no parágrafo único do tipo penal, do elemento subjetivo especial de cometimento do ilícito com o fim de celebrar o contrato com a Administração Pública, no entanto, com relação ao caput, está pacificado na doutrina, principalmente naquela que erigiu-se em torno da vontade do legislador quando instituiu a Lei $n^{\circ}$. 8.666/93, a inexigência do elemento subjetivo especial do tipo.

Na construção legislativa do artigo 89 da Lei de Licitações, basta para a consumação do delito que haja a efetiva celebração do contrato público oriundo da contratação proscrita em lei, não sendo exigida a comprovação de eventual resultado naturalístico a partir desse marco formal viciado.

Atualmente testemunha-se flagrante virada hermenêutica perante as mais altas Cortes do país, eis que, após longos anos de aplicação da norma contida na Lei de Licitações pelo Poder Judiciário, que reconhecia que o tipo em questão se consumava com a mera assinatura do contrato público, ou seja, que se tratava de crime meramente formal.

Este artigo tratará, por isso, da (des) construção do tipo penal capitulado no artigo 89 da Lei $n^{\circ}$. 8.666/93 pela jurisprudência, que passou a exigir a comprovação do elemento subjetivo especial do tipo para fins de aplicação da norma penal no caso concreto, mesmo não sendo essa a opção do legislador.

O estudo também focará nas decisões proferidas pelas Cortes Superiores, em especial nas decisões do Supremo Tribunal Federal, analisando sua força vinculativa.

Derradeiramente, os novos paradigmas jurisprudenciais serão utilizados para avaliar a possibilidade de propositura de ação de revisão criminal para desconstituir as condenações penais transitadas em julgado, que não tenham demonstrado que o agente público tenha agido de forma dolosa, com a finalidade específica de burlar o procedimento licitatório, agregado à comprovação de que no caso concreto tenha havido dano ao erário público.

\section{O ARTIGO 89 DA LEI DE LICITAÇÕES E SUA CONSTRUÇÃO LEGISLATIVA ORIGINAL}

O artigo 89 da Lei de Licitações idealizado pelo legislador definiu que a ocorrência da dispensa ou da inexigibilidade de licitação fora dos casos previstos em lei ou quando se deixa de observar as formalidades pertinentes para tais modalidades de contrações públicas, seriam suficientes para preencher o tipo penal em testilha.

A redação do tipo penal em apreço é muito clara nesse sentido:

Art. 89. Dispensar ou inexigir licitação fora das hipóteses previstas em lei, ou deixar de observar as formalidades pertinentes à dispensa ou à inexigibilidade:

Pena - detenção, de 3 (três) a 5 (cinco) anos, e multa.

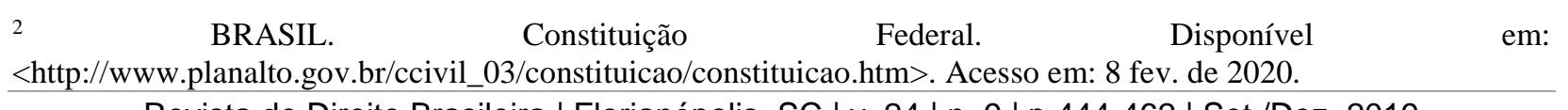


Parágrafo único. Na mesma pena incorre aquele que, tendo comprovadamente concorrido para a consumação da ilegalidade, beneficiou-se da dispensa ou inexigibilidade ilegal, para celebrar contrato com o Poder Público.

A norma erigida criminaliza a conduta daquele que opta por não adotar o procedimento licitatório, quando deveria fazê-lo, ou simplesmente deixa de observar as formalidades necessárias para não licitar.

As hipóteses de dispensa e inexigibilidade de licitação estão elencadas nos artigos 24 e 25 da supracitada lei, cujas formalidades procedimentais estão dispostas na mesma lei em seu artigo 26.

O crime previsto no artigo 89 é classificado pela doutrina como crime próprio ou de mão própria, que identifica-se com as atribuições próprias do exercício das atividades típicas da função pública, contudo, admite a participação do extraneus na condição de partícipe, ainda, especificamente na hipótese do seu parágrafo único, quando o partícipe houver se beneficiado com a celebração do contrato com o Poder Público nas circunstâncias elencadas no caput.

Prega a doutrina que a regra prevista no parágrafo único seria uma exceção à Teoria Monísta da Ação, que limita a responsabilidade penal de "quem, de qualquer modo, concorre para o crime" - artigo 29 do Código Penal ${ }^{3}$ - valendo-se in casu, da determinação prescrita no artigo 12 do Código Penal, aplicando-se também aos fatos incriminados por lei especial, "se esta não dispuser de modo diverso".

Seguindo a toada do legislador, cuja norma não sofreu qualquer mutação no tempo, exsurge como sujeito passivo do crime em tela o Estado-Administração, bem como as entidades de direito público.

Tanto a doutrina quanto a jurisprudência dominante entendem que a pessoa jurídica eventualmente prejudicada, seja pela inobservância do procedimento licitatório ou pela não consecução das formalidades do ato de dispensa ou inexigibilidade do certame licitatório, não se caracterizariam como sujeitos passivos, mediatos ou imediatos, dessa infração penal.

Compreende-se que, no máximo, havendo um terceiro prejudicado pela supressão indevida do procedimento licitatório, restaria a esse terceiro buscar, em ação própria, a reparação do dano na esfera cível.

Como ficou expressado nos motivos elencados pelo legislador, a definição do bem jurídico tutelado nos crimes licitatórios somente poderá ocorrer a partir do exame da política de moralidade administrativa adotada pela Constituição Federal de 1988 e dos Princípios norteadores da Administração Pública.

$\mathrm{O}$ fundamento da criminalização visava impedir eventual procedimento que ofendesse ou dificultasse o tratamento isonômico dos concorrentes e a seleção da proposta mais vantajosa para a Administração Pública; portanto, ancorada nessas premissas é que se erigiu a legislação em apreço.

Seguindo a ritualística clássica de dissecação do tipo penal, vislumbra-se que o tipo objetivo do artigo 89 cuida de crime de ação múltipla ou de conteúdo variado, cujas condutas estão claramente definidas como: 1) dispensar ou; 2) inexigir licitação fora das hipóteses previstas em lei; ou 3) deixar de observar as formalidades a ela pertinentes.

Conforme assentado na jurisprudência pátria, essas condutas consistiriam no ato de declarar dispensada, cujas hipóteses estão definidas claramente em lei (numerus clausus); ou declarar inexigível a licitação fora dos casos previstos em lei, cujo rol de possibilidades é meramente exemplificativo.

3 BRASIL. Decreto-Lei $\mathrm{n}^{\circ}$. 2.848, de 07 de dezembro de 1940. Código Penal Disponível em: <http://www.planalto.gov.br/ccivil_03/decreto-lei/del2848compilado.htm>. Acesso em: 6 de fev. de 2020. 
Além disso, de acordo com a norma, também seria ilícita a formalização de contratação pública diante da inexistência da situação fática que legitimaria a dispensa ou inexigibilidade, como por exemplo, a fabricação de uma situação emergencial.

Por fim, o tipo penal analisado criminaliza a conduta direcionada daquele que deixa de observar as formalidades pertinentes à dispensa ou à inexigibilidade de licitação, como desrespeito aos ritos, prazos, documentos e outras situações semelhantes.

Nesse aspecto há forte crítica da doutrina acerca do exagero do legislador em criminalizar o erro administrativo. Cezar Roberto Bitencourt ${ }^{4}$ tece os seguintes comentários sobre isso:

Constata-se, nessa hipótese, um claro exagero do legislador criminalizando um simples erro administrativo, sem objetividade jurídica punível identificável, além de não produzir qualquer lesão ao patrimônio público ou mesmo a propalada ordem pública (de difícil identificação!). A rigor, temos dificuldade em aceitar a constitucionalidade dessa criminalização, que peca pelo excesso, violando, em outros termos, o princípio da proporcionalidade, considerando-se que mero error in procedendo, além de indevidamente criminalizado, é sancionado com pena de três a cinco anos de detenção e multa. Ademais, é extremamente difícil apurar-se a existência de elemento subjetivo orientador da conduta equivocada do servidor público.

Outro ponto que tem causado algumas divergências na doutrina refere-se à possibilidade ou não da criação de complementos normativos oriundos outras esferas (Estadual ou Municipal), estabelecendo maiores restrições do que aquelas previstas na própria Lei nº. 8.666/93.

A doutrina dominante propugna que as hipóteses de dispensa ou inexigibilidade de licitação devem ser apenas aquelas previstas na Lei de Licitações, diante do que classificam o artigo 89 como norma penal em branco homóloga.

Cezar Roberto Bitencourt ${ }^{5}$ sustenta que outros complementos normativos, de outras esferas, se existirem, se limitarão ao plano administrativo, podendo anular o edital ou o próprio certamente licitatório, mas não produz efeitos na lei incriminadora.

Por outro lado, André Tavares de Freitas $^{6}$, divergindo da posição adotada por BITENCOURT, sustenta que:

Eventualmente, as regras a serem observadas nos casos de dispensa ou inexigibilidade de licitação podem estar dispostas em outras sedes além do art. 26 desta lei. Como 'leis ou atos estatais, distritais e municipais existentes ou por serem editados'. Podem estabelecer outras formalidades para completar o tipo penal em branco.

No entanto, a posição acima reproduzida não encontra guarida jurisprudencial, pois ampliaria de forma extrema as possibilidades de tipificação do crime previsto no art. 89 da Lei de Licitações, inclusive criando situações divergentes na aplicação da norma incriminadora em cada Município ou Estado.

Já o elemento subjetivo das condutas é o dolo, constituído pela consciência e a vontade de realização das condutas descritas no tipo penal, quais sejam, dispensar ou inexigir licitação fora das hipóteses legais, ou deixar de observar as formalidades pertinentes à dispensa ou à inexigibilidade.

\footnotetext{
${ }^{4}$ BITENCOURT, Cezar Roberto. Direito Penal das Licitações. 1 ed. São Paulo: Saraiva, 2012, p.148.

${ }^{5}$ BITENCOURT, 2012, p. 150-151.

${ }^{6}$ FREITAS, André Guilherme Tavares de. Crimes na Lei de Licitações. Rio de Janeiro: Lumen Juris, $2007,75$. Revista de Direito Brasileira | Florianópolis, SC | v. 24 | n. 9 | p.444-462 | Set./Dez. 2019
} 
No que tange as elementares objetiva e subjetiva constantes do caput do artigo 89, não existe na dicção original dada ao tipo penal a exigência do denominado elemento subjetivo especial do tipo ou do injusto, como por exemplo, o especial fim de agir.

Parte da doutrina sustenta que a figura contida no parágrafo único da norma conteria o elemento subjetivo especial na hipótese de comprovada a atuação direcionada ao cometimento da ilegalidade, cujo fim seria de celebrar contrato com o Poder Público, contudo, essa corrente não ressoou na jurisprudência. Essa linha interpretativa é liderada por Rui Stoco ${ }^{7}$ e Vicente Greco Filho $^{8}$

Cesar Roberto Bitencourt ${ }^{9}$ discorda da opinião acima reproduzida, concebendo que o parágrafo único contém um tipo penal classificado como crime material, que somente se consuma com a efetiva contratação pública, e, se for considerada a finalidade de assinar o contrato como elementar do tipo, ou melhor, como elemento subjetivo especial do injusto, essa concretização seria desnecessária.

No entanto, preferimos interpretar essa elementar como se fora uma espécie de condição objetiva de punibilidade (a despeito de integrar o tipo penal), pois consideramos que a conduta incriminada somente se consuma com a efetiva contratação do agente com o Poder Público, embora reconheçamos ser bem razoável a interpretação de Greco e Stoco.

$\mathrm{Na}$ verdade, concebemos essa infração penal como crime material, que somente se consuma com a efetiva contratação pública, e, se for considerada aquela elementar, como elemento subjetivo do injusto, essa concretização seria desnecessária.

Portanto, finalizando o processo de dissecação do tipo penal idealizado pelo legislador quando da promulgação da Lei $\mathrm{n}^{\circ}$. 8.666/93, conclui-se que o crime capitulado no artigo 89 somente consuma-se com a efetiva celebração do contrato licitatório, mesmo antes de efetivada a sua execução.

Em vista disso, fica praticamente impossível comprovar a existência ou não de vontade e consciência de descumprir o comando legal antes disso; é possível, inclusive, que os trâmites administrativos sejam até cancelados, situação essa que impede a concretização do tipo penal.

Essa era, portanto, a visão geral que a doutrina e a jurisprudência tinham em relação ao crime capitulado no artigo 89 da Lei de Licitações, cujo viés interpretativo vem sendo redesenhado nos últimos dois anos, com profunda alteração jurisprudencial, a qual passará a ser tratada nos tópicos seguintes deste estudo.

\section{A EXIGÊNCIA DE COMPROVAÇÃO DO ELEMENTO SUBJETIVO ESPECIAL DO TIPO}

Diante da abertura do tipo penal previsto no artigo 89 da Lei de Licitações, especialmente na parte que criminaliza os erros administrativos, independente do resultado ou de lesão ao erário público, fez com que avolumasse o número de ações penais propostas pelo Ministério Público em face de agentes públicos.

A mera realização de procedimentos de dispensa ou inexigibilidade de licitação fora dos casos previstos em lei ou diante da ausência de uma de suas formalidades, permitia a movimentação da máquina repressiva estatal, dispensando que a peça acusatória apontasse a ocorrência de prejuízo

\footnotetext{
${ }^{7}$ Vicente Greco Filho, Dos crimes da Lei de Licitações. 2. ed., São Paulo: Saraiva, 2007, p. 63.

${ }^{8}$ STOCCO, Rui. Leis penais e sua interpretação jurisprudencial. 7. ed., São Paulo: Revista dos Tribunais, 2001, v. 3, p. 2560.

${ }^{9}$ BITENCOURT, 2012, p. 162.
} 
ao erário, benefício pessoal aos contratados ou mesmo qualquer espécie de vantagem ilícita em favor do agente público.

É exatamente neste ponto que se assentou a virada hermenêutica objeto do presente estudo, já que a interpretação acerca do tipo previsto no artigo 89 da Lei de Licitações, alavancada pelas Cortes judiciais, passou a exigir a comprovação do dolo específico de burla o procedimento licitatório com o fito de causar prejuízo ao erário ou que tenha por objetivo angariar qualquer espécie de benefício pessoal ao agente público; ou que o contratado (particular) aja focado em locupletar-se ilicitamente em detrimento do erário público. Inclusive, nessa última hipótese a modalidade penal se tornaria um verdadeiro crime-meio ao peculato.

Apesar da construção legislativa do tipo penal analisado não ter estabelecido o elemento subjetivo especial do tipo, muito menos ter exigido o resultado para a consumação do delito, passou hodiernamente a jurisprudência dominante a impor que a ação penal aponte claramente o resultado naturalístico em razão da burla à licitação ou em razão do descumprimento de suas formalidades intrínsecas.

O resultado naturalístico passou a integrar o tipo penal previsto no artigo 89 da Lei de Licitações, contrariando a própria construção normativa idealizada pelo legislador; houve uma indisfarçável (des) construção do tipo penal em voga, passando a jurisprudência a exigir a comprovação do elemento subjetivo especial do tipo; ou seja, alterou-se a própria classificação de crime formal para crime material, que exige a demonstração da ocorrência do resultado naturalístico.

O que chama a atenção no caso vertente é a alteração da própria estrutura do tipo penal pelo Poder Judiciário, acrescentando o elemento subjetivo especial à norma, porém, o próprio legislador optou por prescindir o especial fim de agir para a configuração do crime.

Ademais, a jurisprudência passou a impor a comprovação do resultado naturalístico para que a conduta do agente passe a ser considerada um ilícito penal, ao passo que o legislador apenas exigiu que a dispensa ou inexigibilidade da licitação seja realizada fora das hipóteses previstas em lei ou mediante a supressão de suas formalidades essenciais, bastando para consumar-se o delito, nessa hipótese, que o contrato com a Administração Pública seja celebrado.

Para melhor aclarar a narrada remodulação do artigo 89 da Lei de Licitações, no tópico seguinte serão analisadas as recentes decisões proferidas pelo Supremo Tribunal Federal e pelo Superior Tribunal de Justiça que dão sustentáculo a esta pesquisa científica.

\section{A (DES) CONSTRUÇÃO DO TIPO PENAL PREVISTO NO ARTIGO 89 DA LEI No. 8.666/93 PELA JURISPRUDÊNCIA}

São inúmeras as decisões do Supremo Tribunal Federal e do Superior Tribunal de Justiça que exigem para a caracterização do crime previsto no artigo 89 da Lei de Licitações, que, cumulativamente, seja comprovado o dolo específico de burla ao procedimento licitatório, agregado à hipótese da existência de provas acerca do prejuízo ao erário ou que tenha havido benefício pessoal ao agente público ou ao terceiro (extraneus), em detrimento do erário público.

Vislumbra-se nesta pesquisa que a jurisprudência literalmente desconstruiu o artigo 89 da Lei $n^{\circ}$. 8.666/93, acrescentando o resultado naturalístico como elemento integrante do tipo penal.

Através da interpretação sistemática foi possível analisar o papel da jurisprudência para a construção ou desconstrução de tipo penal em destaque, notadamente investigando o caso específico em evidência e a inclusão do elemento subjetivo especial do tipo à norma e o prejuízo ao erário como requisito para a violação ao tipo penal, independentemente de sua previsão pelo legislador.

Também mereceram profundas investigações as inúmeras ações penais que tramitam em face de servidores públicos por todo o Brasil, muitas delas imputando como ilícitas as suas condutas por mera violação às formalidades legais atinentes às dispensas ou inexigibilidades de licitações, 
sem a demonstração do resultado naturalístico decorrente da conduta incriminada, em detrimento da assentada jurisprudência sobre o tema.

Com o novo paradigma decisório, o Ministério Público incumbiu-se de demonstrar referidos elementos, portanto, na inicial acusatória deve apontar claramente que a conduta do acusado está ancorada no agir dolo e com o especial fim de causar prejuízo ao erário ou beneficiarse de qualquer forma em razão da dispensa ou inexigibilidade de licitação, apontando o resultado naturalístico desse agir direcionado.

Antes de analisar de forma pormenorizada as decisões recentes proferidas pelo Supremo Tribunal Federal e pelo Superior Tribunal de Justiça, é importante citar o posicionamento de Marçal Justen Filho ${ }^{10}$ sobre o tema:

[...] O elemento subjetivo [do artigo 89] consiste não apenas na intenção maliciosa de deixar de praticar a licitação cabível. [...] É imperioso, para a caracterização do crime, que o agente atue voltado a obter um outro resultado, efetivamente reprovável e grave, além da mera contratação direta. Ocorre, assim, a conduta ilícita quando o agente possui a vontade livre e consciente de produzir o resultado danoso ao erário. É necessário um elemento subjetivo consistente em produzir prejuízo aos cofres públicos por meio do afastamento indevido de licitação. Portanto, não basta a mera intenção de não realizar licitação em um caso em que tal seria necessário.

A manifesta expressão doutrinária acima citada já vem sendo construída muito antes da consolidação da (des) construção da norma incriminadora pela jurisprudência, cujo posicionamento reclamava a comprovação da finalidade de causar prejuízo ao erário, não bastando a mera intenção de não realizar a licitação ou deixar de atender eventual formalidade intrínseca à dispensa ou inexigibilidade.

Nesta esteira, a Sexta Turma do Superior Tribunal de Justiça, em 2017, proferiu a seguinte decisão:

HABEAS CORPUS. DISPENSA DE LICITAÇÃO FORA DAS HIPÓTESES PREVISTAS EM LEI. ELEMENTO SUBJETIVO ESPECIAL. INTENÇÃO DE LESAR O PATRIMÔNIO PÚBLICO. EFETIVO PREJUÍZO AO ERÁRIO. DOLO ESPECÍFICO NÃO INDICADO. RECURSO PROVIDO.1. Consoante o entendimento consolidado pelo Superior Tribunal de Justiça, a partir da APn n. 480, para a imputação do delito previsto no art. 89 da Lei n. 8.666/1993 é necessária a demonstração do dolo específico de causar dano ao erário e a configuração do efetivo prejuízo ao patrimônio público.

$[\ldots]$

3. Na espécie, o Ministério Público estadual, em sua peça acusatória, imputou aos recorrentes a conduta delitiva em análise, alicerçado tão somente no desempenho tópico da função pública por eles exercida - ao elaborarem parecer acerca da possibilidade de não realização de processo licitatório - sem demonstrar a vontade de provocar lesão ao erário, tampouco a ocorrência de prejuízo. 4. Recurso provido para reconhecer a atipicidade da conduta perpetrada pelos recorrentes e trancar, ab initio, o processo movido contra ambos. (HC n. 337.218/MG, Relator Ministro Rogerio Schietti Cruz, 6a T, DJe 27/10/2017).

No caso analisado acima foi reconhecida a atipicidade da conduta do advogado que emitiu parecer jurídico em contratação por dispensa de licitação, pois não foi comprovado que o advogado,

${ }^{10}$ JUSTEN FILHO, Marçal. Comentários à Lei de Licitações e Contratos Administrativos. 14 ed. São Paulo: Dialética, 2010, p. 901-904. 
no exercício de sua função pública, tinha agido com vontade de provocar lesão ao erário, muito menos foi demonstrado no caso concreto a ocorrência de prejuízo aos cofres públicos.

O Superior Tribunal de Justiça pacificou o entendimento no sentido de ser obrigatória a indicação na peça acusatória do dolo específico de causar prejuízo ao erário, bem como da quantificação do dano suportado pela Administração Pública.

A Quinta Turma do Superior Tribunal de Justiça, em recente decisão, citando precedentes do Supremo Tribunal Federal, proferiu o seguinte escólio:

PENAL E PROCESSO PENAL. HABEAS CORPUS SUBSTITUTIVO DE RECURSO.INADEQUAÇÃO. ART. 89 DA LEI N. 8.666/1993. DISPENSA OU INEXIGIBILIDADE DE LICITAÇÃO FORA DAS HIPÓTESES PREVISTAS EM LEI. DOLO ESPECÍFICO. EFETIVO PREJUÍZO AO ERÁRIO. COMPROVAÇÃO. NECESSIDADE. ATIPICIDADE DA CONDUTA NARRADA NA DENÚNCIA. ART. 580 DO CPP. WRIT NÃO CONHECIDO. ORDEM CONCEDIDA DE OFÍCIO, COM EXTENSÃO AOS CORRÉUS.

$[\ldots]$

2. A jurisprudência desta Corte Superior acompanha o entendimento do Pleno do Supremo Tribunal Federal (Inq. n. 2.482/MG, julgado em 15/9/2011), no sentido de que a consumação do crime do art. 89 da Lei n. 8.666/1993 exige a demonstração do dolo específico, ou seja, a intenção de causar dano ao erário e a efetiva ocorrência de prejuízo aos cofres públicos, malgrado ausência de disposições legais acerca dessa elementar.

$[\ldots]$.

(HC n. 476.051/TO, Ministro Ribeiro Dantas, Quinta Turma, julgado em 7/5/2019, DJe 13/5/2019)

A decisão acima elencada deixa evidente a temática desse estudo, realçando que malgrado a ausência de disposições legais acerca da elementar, ou seja, do elemento subjetivo especial do tipo não estar presente na construção original da norma, mas acompanhando o entendimento consolidado pelo Supremo Tribunal Federal, passou-se a exigir a demonstração efetiva da intenção de causar dano ao erário e a sua efetiva ocorrência.

Por sua vez, o Supremo Tribunal Federal, no ano de 2016, através de Acórdão relatado pela Ministra Cármen Lúcia, destacou que:

EMENTA: AÇÃO PENAL. DEPUTADO FEDERAL. IMPUTAÇÃO DA PRÁTICA DOS CRIMES DE PECULATO (ART. 312 DO CÓDIGO PENAL) E DISPENSA IRREGULAR DE LICITAÇÃO (ART. 89 DA LEI DE LICITAÇÕES). ACOLHIMENTO DO PEDIDO DE ABSOLVIÇÃO FEITO PELO PROCURADOR-GERAL DA REPÚBLICA QUANTO AO CRIME DE PECULATO. IMPROCEDÊNCIA DO PEDIDO DE CONDENAÇÃO PELA ALEGADA PRÁTICA DO CRIME DO ART. 89 DA LEI N. 8.666/1993. DISPENSA DE LICITAÇÃO QUE ATENDEU AOS REQUISITOS LEGAIS. AUSÊNCIA DE DOLO ESPECÍFICO DE CAUSAR DANO AO ERÁRIO. ABSOLVIÇÃO DE AMBAS AS IMPUTAÇÕES. AÇÃO PENAL IMPROCEDENTE.

[...]

3. A incidência do crime do art. 89 da Lei n. 8.666/1993 depende da presença de elemento subjetivo do agente político: a vontade livre e consciente de lesar o erário, pois assim garante-se a necessária distinção entre atos próprios do cotidiano político administrativo e atos que revelam o cometimento de ilícitos penais. 4. Ação penal julgada improcedente. (AP 917, Relator(a): Min. CÁRMEN LÚCIA, Segunda Turma, julgado em 


\section{7/06/2016, ACÓRDÃO ELETRÔNICO DJe-244 DIVULG 24-10-2017 \\ PUBLIC 25-10-2017)}

A decisão em evidência gizou que eventual condenação pelo crime previsto no artigo 89 da Lei de Licitações depende precipuamente da presença do elemento subjetivo especial do tipo, ou seja, a vontade livre e consciente de lesar o erário público.

A decisão sublinha a necessidade de distinção entre os atos próprios do cotidiano político administrativo e os atos que revelam o cometimento de ilícitos penais, não sendo crível a intervenção do Direito Penal quando não presentes a intenção direcionada à causação do dano ao erário público e sua efetiva ocorrência.

Por conseguinte, no ano de 2018, ficou demonstrada a saturação do tema perante o Pretório Excelso sobre a aplicação do artigo 89 da Lei de Licitações, restringindo-se aos casos específicos em que se comprove o resultado finalístico da ação, que têm-se concedido inúmeros habeas corpus, até ex officio, para trancar ações penais que se aventuram na tese acusatória do crime meramente formal.

EMENTA Agravo regimental em habeas corpus. Penal. Dispensa ou inexigibilidade de licitação fora das hipóteses legais. Artigo 89 da Lei no 8.666/93. Pretendido trancamento da ação penal. Inépcia da denúncia. Atipicidade da conduta imputada. Ausência de demonstração do dolo específico. Agravante que, na qualidade de chefe da Assessoria Técnica da Administração Regional, emitiu parecer favorável a contratação. Manifestação de natureza meramente opinativa e, portanto, não vinculante para o gestor público, o qual pode, de forma justificada, adotar ou não a orientação exposta no parecer. O parecer tem natureza obrigatória (art. 38, VI, da Lei no 8.666/93), porém não é vinculante. Ineficiência da denúncia na demonstração da vontade conscientemente dirigida, por parte da agravante, de superar a necessidade de realização da licitação. Abusividade da responsabilização do parecerista à luz de uma alargada relação de causalidade entre seu parecer e o ato administrativo do qual tenha supostamente resultado dano ao erário (v.g., MS n ${ }^{\circ}$ 24.631/DF, Tribunal Pleno, Relator o Ministro Joaquim Barbosa, DJe de 1\%/2/08). Agravo regimental ao qual se dá provimento para conceder a ordem de habeas corpus e trancar a ação penal à qual responde a agravante.

$[\ldots]$

10. Tal conclusão se robustece quando se torna evidente, para além do dolo simples necessário (vontade consciente de contratar independentemente da realização de procedimento licitatório), que o Parquet não apresentou, na denúncia, elemento probatório mínimo que demonstrasse qualquer tipo de intenção por parte da agravante de produzir um prejuízo aos cofres públicos por meio do afastamento indevido da licitação. 11. A ausência de observância das formalidades pertinentes à dispensa ou à inexigibilidade da licitação somente é passível de sanção quando acarretar contratação indevida e houver demonstração da vontade ilícita do agente em produzir um resultado danoso, o que não foi $o$ caso. 12. Agravo regimental ao qual se dá provimento para conceder a ordem de habeas corpus e trancar a ação penal em relação à agravante.

(HC 155020 AgR, Relator(a): Min. CELSO DE MELLO, Relator(a) p/ Acórdão: Min. DIAS TOFFOLI, Segunda Turma, julgado em 04/09/2018, PROCESSO ELETRÔNICO DJe-233 DIVULG 31-10-2018 PUBLIC 05-112018)

O Acórdão de relatoria do Ministro Celso de Mello destaca que a ausência da observância das formalidades atinentes à dispensa ou inexigibilidade de licitação, de per si, não são suficientes para preencher o tipo penal capitulado no artigo 89 da Lei de Licitações, pois a contratação indevida 
precisaria ter sido realizada à vista de vontade ilícita do agente em produzir o resultado danoso, ou seja, de causar prejuízo ao erário público.

A mais recente decisão do Supremo Tribunal Federal, proferida no final do ano de 2019, de relatoria para o Acórdão do Ministro Luiz Fux, bem retrata a (des) construção jurisprudencial da norma em voga:

Ementa: AÇÃO PENAL. DIREITO PENAL. DISPENSA ILÍCITA DE LICITAÇÃO E PECULATO (ART. 89 DA LEI 8.666/3 E ART. 312 DO CÓDIGO PENAL). AQUISIÇÃO DE LIVROS DIDÁTICOS. SUFICIÊNCIA, PARA A DISPENSA DE LICITAÇÃO, DO PARECER DA PROCURADORIAGERAL DO ESTADO NO SENTIDO DA IDONEIDADE DAS CARTAS DE EXCLUSIVIDADE CONCEDIDAS PELAS EDITORAS ÀS DISTRIBUIDORAS CONTRATADAS. AUSENTE INDÍCIO DE INTERFERÊNCIA DA ACUSADA PARA FAVORECER TERCEIROS. AUSÊNCIA DE PESQUISA DE PREÇOS QUE, EM CASO DE IMPOSSIBILIDADE DE CONCORRÊNCIA NO MERCADO, CONFIGURA MERA IRREGULARIDADE. AUSENTE, ADEMAIS, DEMONSTRAÇÃO DE SOBREPREÇO, CONFORME TOMADA DE CONTAS DO TCU. LAUDOS PERICIAIS FUNDADOS EM PREÇOS DISTINTOS DOS PRATICADOS À ÉPOCA DOS FATOS. ABSOLVIÇÃO (ART. 386, II E III, DO CPP).

$[\ldots]$

2. (a) A inobservância dos critérios legais de inexigibilidade deve somar-se, para a tipificação do crime do art. 89 da Lei 8.666/93, à vontade de frustrar, indevidamente, a concorrência pública, revelando-se incabível enfoque puramente causal, desatento aos elementos subjetivos integrantes do tipo (Teoria Final da Ação). (b) Consectariamente, revela-se imperioso, para a caracterização do crime do art. 89 da Lei 8.666/93, que o agente atue voltado à frustração da concorrência e à produção de dano ao erário.

$[\ldots]$

9. Ex positis, julgo improcedente a denúncia para absolver a Ré quanto ao art. 89 da Lei 8.666/93, por não constituir o fato infração penal (art. 386, III, do Código de Processo Penal); e quanto ao art. 312 do Código Penal, por não haver prova da existência do fato delitivo (art. 386, II, do Código de Processo Penal).

(AP 962, Relator(a): Min. MARCO AURÉLIO, Relator(a) p/ Acórdão: Min. LUIZ FUX, Primeira Turma, julgado em 04/06/2019, ACÓRDÃO ELETRÔNICO DJe-230 DIVULG 22-10-2019 PUBLIC 23-10-2019).

É tão marcante a virada hermenêutica ocorrida perante as Cortes Superiores que seus efeitos estão ressoando na esfera das ações de improbidade administrativa, exigindo que a conduta desonesta do agente público não basta para sua responsabilização por atos ímprobos, necessitando, pois, que o prejuízo ao patrimônio público seja verificado.

\section{A POSSIBILIDADE DE PROPOSITURA DA AÇÃO DE REVISÃO CRIMINAL DIANTE DO NOVO PARADIGMA JURISPRUDENCIAL IN BONAN PARTEM}

Conforme se extrai do art. $5^{\circ}$, inciso XL da Constituição Federal de 1988, que eventual alteração legislativa na seara criminal efetivada in bonan partem, pode retroagir em favor do acusado ou do condenado criminalmente.

O Código de Processo Penal ${ }^{11}$ prevê expressamente a ação de revisão criminal como mecanismo processual adequado para que a sentença penal condenatória, já transitada em julgado,

${ }_{11}$ BRASIL. Decreto- Lei no ${ }^{\circ}$ 3.689, de 3 de outubro de 1941. Código de Processo Penal. Disponível em: < http://www.planalto.gov.br/ccivil_03/decreto-lei/del3689compilado.htm >. Acesso em: $11 \mathrm{fev}$. de 2020.

Revista de Direito Brasileira | Florianópolis, SC | v. 24 | n. 9 | p.444-462 | Set./Dez. 2019 
possa passar novamente pelo crivo do Poder Judiciário e literalmente rescindir a condenação injusta, seja ela mediante novas provas que alterem o caminhar dos fatos típicos ou mesmo diante de eventual descriminalização da conduta do condenado.

Além disso, rotineiramente a ação de revisão criminal tem sido utilizada como mecanismo para readequação de penas criminais já consolidadas pelo fator tempo, quando sobrevém alteração legislativa que confere ao tipo penal penas mais brandas.

Enfim, o sistema processual penal pátrio certamente relativizou o instituto jurídico da coisa julgada em relação ao condenado, permitindo-lhe a qualquer momento, mesmo após o cumprimento da pena, buscar a revisão de sua condenação.

E mais, até após a morte do condenado poderão seus familiares obter pronunciamento judicial visando a reapreciação da condenação, cujos efeitos certamente são direcionados à preservação da honra do de cujus ou com fito de obter eventual reparação de danos na esfera cível.

Acontece que o caso em tela não trata de nenhuma das hipóteses, muito menos se está diante de alteração legislativa in bonan partem promovida pelo legislador, todavia, está presente uma clara (des) construção do tipo penal previsto no artigo 89 da Lei de Licitações, arquitetada pelo Poder Judiciário, através de repetidas decisões do Supremo Tribunal Federal e do Superior Tribunal de Justiça.

Pelo que já foi exposto nesse artigo, não houve qualquer alteração na redação do tipo penal em apreço, cuja construção legislativa está intacta, como idealizada pelo legislador, contudo, perante o Poder Judiciário acrescentou-se a exigência de comprovação de conduta dolosa direcionada à confecção de contratação pública sem licitação, fora dos casos previstos em lei, ou que a dispensa ou inexigibilidade do certame seja concretizada sem a obediência dos requisitos legais que lhe são característicos.

E mais, a jurisprudência agregou a exigência de comprovação do elemento subjetivo especial do tipo - o fim de agir - à ocorrência de dano ao erário público, cujas elementares não estão presentes na construção normativa original da Lei de Licitações.

É bom mencionar que não se tem notícia ainda sobre a edição de Súmula Vinculante pelo Pretório Excelso ou mesmo de Súmula do Superior Tribunal de Justiça sobre o tema, porém, conforme citado nesse artigo, são inúmeras as decisões que alteraram o paradigma interpretativo sobre o crime previsto no artigo 89 da Lei de Licitações.

Conforme propugnado pela doutrina, caberá ao Poder Judiciário o papel de intérprete da legislação, cujo objetivo é a estabilidade do ordenamento jurídico, atendendo aos critérios de coerência e integridade.

Ocorre, como já foi dito, que a norma incriminadora analisada neste caso não espelha as decisões proferidas pelo Poder Judiciário, entretanto, a norma continua em plena vigência, não tendo sido reconhecida sua inconstitucionalidade ou incongruência com o sistema jurídico vigente.

A virada hermenêutica que está em curso é indisfarçável, no entanto, parte da doutrina insiste em negar às decisões judiciais seu efeito vinculativo pleno, exceto nas hipóteses elencadas na própria Constituição de $1988^{12}$; contudo, não é crível que se propugne deixar de acompanhar, por exemplo, os posicionamentos do Supremo Tribunal Federal, pois a segurança jurídica ficaria comprometida.

Adiante se transcreve a posição de Lenio Streck sobre a matéria:

\footnotetext{
${ }^{12}$ Art. 102. Compete ao Supremo Tribunal Federal, precipuamente, a guarda da Constituição, cabendo-lhe:

[...]

$\S 2^{\circ}$ As decisões definitivas de mérito, proferidas pelo Supremo Tribunal Federal, nas ações diretas de inconstitucionalidade e nas ações declaratórias de constitucionalidade produzirão eficácia contra todos e efeito vinculante, relativamente aos demais órgãos do Poder Judiciário e à administração pública direta e indireta, nas esferas federal, estadual e municipal.
}

Revista de Direito Brasileira | Florianópolis, SC | v. 24 | n. 9 | p.444-462 | Set./Dez. 2019 
Por isso, somente pode ser vinculante a decisão na qual o Tribunal atua como legislador negativo, expungindo (no plano da validade) o texto normativo do sistema. Na contramão, quando, de um modo ou de outro, o tribunal estabelecer um sentido conformador com a Constituição, necessariamente estará agregando sentido. Isso é inexorável, pois, caso contrário, o texto deve ser declarado inconstitucional. Parece evidente isso! Ou seja, se o texto não pode ser "salvo", deve ser retirado / expungido do ordenamento. E essa adição de sentido ao texto original é um dos sentidos possíveis a adicionar, não podendo, destarte, de forma vinculativa, impedir-se que os demais tribunais encontrem outras maneiras para a aplicação daquele texto. As circunstâncias histórico-factuais-temporais sempre demandarão novas incidências, novas "sínteses ontológico-existenciais". ${ }^{13}$

Gilmar Ferreira Mendes defende que as decisões proferidas em sede de recurso extraordinário convertam-se em diretrizes interpretativas gerais.

Ainda no plano da eficácia, cumpre referir decisões em recursos extraordinários nas quais o Tribunal, em homenagem à segurança jurídica ou a outro valor constitucional relevante, modulou efeitos do decisum. Conforme assentado na decisão proferida no HC 82.959 (progressão de regime nos crimes hediondos), a limitação dos efeitos é um apanágio do controle da constitucionalidade, e razão jurídica não há para que tal instrumento, veículo mediante o qual a Corte pode integrar ao seu afazer o princípio da segurança jurídica, não seja também utilizado em sede de controle incidental. As normas contidas nos arts. 27 da Lei ${ }^{\circ} 9.868$ e 11 da Lei $n^{\circ}$ 9.882, ambas de 1999, nesse sentido, menos que instrumentos procedimentais do controle abstrato, convertem-se em diretrizes interpretativas gerais. ${ }^{14}$

O autor defende que não só as decisões proferidas em sede positiva ou negativa de constitucionalidade, de caráter amplo, de controle da constitucionalidade concreta podem ter efeitos erga omnes, mas, apesar de tecnicamente as decisões nos recursos extraordinários não possuírem este efeito natural, certamente que devem ser utilizadas pelo sistema judiciário, nas suas mais variadas esferas e graus, como diretrizes interpretativas gerais e guia de suas decisões.

O Ministro Marco Aurélio, suscitando questão de ordem no julgamento do Recurso Extraordinário nº. 353.657, acrescentou que:

Considerou, por outro lado, que essas normas, na medida em que simplesmente autorizam o STF a restringir os efeitos da declaração de inconstitucionalidade, sem qualquer outra limitação expressa, a rigor não excluem a modulação da própria eficácia subjetiva da decisão, permitindo que se circunscreva o seu alcance, em geral erga omnes, a um universo determinado de pessoas, bem como não afastam a possibilidade de desconsiderar-se o efeito repristinatório da decisão de inconstitucionalidade sobre o ato revogado. Aduziu que, não obstante esse poder conferido ao STF de regular os efeitos das decisões proferidas no bojo de ações de natureza objetiva não se encontre previsto em nenhum dispositivo do texto constitucional, por força do art. 102, caput, da CF, o STF exerce o papel de "guarda da Constituição", múnus de matiz político, cujo exercício admite considerável margem de discricionariedade exatamente para que ele possa dar efetividade ao princípio da supremacia constitucional. Ressaltou que o STF, ao proceder, em casos excepcionais, à modulação dos efeitos de suas decisões, por motivos de segurança jurídica ou de relevante interesse social, realiza a

\footnotetext{
${ }^{13}$ STRECK, Lenio Luiz. Jurisdição Constitucional e Hermenêutica: uma nova crítica do Direito. Porto Alegre: Livraria do Advogado, 2002, p. 489.

${ }^{14}$ MENDES, Gilmar Ferreira. Curso de Direito Constitucional. 13 ed. São Paulo: Saraiva Educação, 2018, p. 1083. Revista de Direito Brasileira | Florianópolis, SC | v. 24 | n. 9 | p.444-462 | Set./Dez. 2019
} 
ponderação de valores e de princípios abrigados na própria Constituição. Tendo isso em conta, o Min. Ricardo Lewandowski afirmou que os fundamentos, que autorizam a modulação dos efeitos das decisões prolatadas nos processos de índole objetiva, se aplicam, mutatis mutandis, aos processos de índole subjetiva. No ponto, citando jurisprudência da Corte nesse sentido (RE 197917/SP, DJU de 7.5.2004), assentou que, embora se esteja tratando, no caso, de processos subjetivos, quando a matéria é afetada o Plenário, a decisão resultante, na prática, surtirá efeitos erga omnes. Registrou, por fim, o fato de que, em duas ocasiões anteriores, o Plenário manifestara-se favoravelmente, por maioria, ao creditamento do IPI nas operações de que tratam os recursos sob exame, tendo sido tomadas, com base nessas decisões, várias outras, no STF, no STJ e nos Tribunais Regionais Federais. Após, o julgamento foi suspenso em virtude do pedido de vista do Min. Marco Aurélio. ${ }^{15}$

A decisão acima transcrita ressalta que os mesmos fundamentos que autorizam a modulação dos efeitos das decisões de índole objetiva, ressalvadas algumas mudanças estruturais, aplicam-se às decisões de índole subjetiva.

Quando o Recurso Extraordinário é apreciado pelo Plenário do Supremo Tribunal Federal, mesmo sendo ação que não visa o controle concentrado da constitucionalidade, negativa ou positiva, de acordo com a decisão citada, surtiria efeitos erga omnes.

A decisão analisada ainda faz referência ao julgamento proferido no Recurso Extraordinário no ${ }^{\circ}$ 197.917:

RECURSO EXTRAORDINÁRIO. MUNICÍPIOS. CÂMARA DE VEREADORES. COMPOSIÇÃO. AUTONOMIA MUNICIPAL. LIMITES CONSTITUCIONAIS. NÚMERO DE VEREADORES PROPORCIONAL À POPULAÇÃO. CF, ARTIGO 29, IV. APLICAÇÃO DE CRITÉRIO ARITMÉTICO RÍGIDO. INVOCAÇÃO DOS PRINCÍPIOS DA ISONOMIA E DA RAZOABILIDADE. INCOMPATIBILIDADE ENTRE A POPULAÇÃO E O NÚMERO DE VEREADORES. INCONSTITUCIONALIDADE, INCIDENTER TANTUM, DA NORMA MUNICIPAL. EFEITOS PARA O FUTURO. SITUAÇÃO EXCEPCIONAL.

[...]

7. Inconstitucionalidade, incidenter tantun, da lei local que fixou em 11 (onze) o número de Vereadores, dado que sua população de pouco mais de 2600 habitantes somente comporta 09 representantes. 8. Efeitos. Princípio da segurança jurídica. Situação excepcional em que a declaração de nulidade, com seus normais efeitos ex tunc, resultaria grave ameaça a todo o sistema legislativo vigente. Prevalência do interesse público para assegurar, em caráter de exceção, efeitos pro futuro à declaração incidental de inconstitucionalidade. Recurso extraordinário conhecido e em parte provido.

(RE 197917, Relator(a): Min. MAURÍCIO CORRÊA, Tribunal Pleno, julgado em 06/06/2002, DJ 07-05-2004 PP-00036 EMENT VOL-02150-03 PP-00368) ${ }^{16}$

Nesta decisão do órgão pleno do Pretório Excelso, ressaltou-se o princípio da segurança jurídica, com o fito de preservar o interesse público, em caráter excepcional, conferindo efeitos futuros à declaração incidental de inconstitucionalidade.

\footnotetext{
${ }^{15}$ BRASIL. Supremo Tribunal Federal. RE n 353.657, rel. Min. Marco Aurélio, DJE 25/06/2007, Informativo STF n ${ }^{\circ}$ 463, $\quad 16$ a 20/04/2007. Disponível em: http://redir.stf.jus.br/paginadorpub/paginador.jsp?docTP=TP\&docID=7303880>. Acesso em 9 fev. de 2020.

16 BRASIL. Supremo Tribunal Federal. Recurso Extraordinário no ${ }^{\circ}$ 197917, Rel. Min. MAURÍCIO CORRÊA, Tribunal Pleno, julgado em 06/06/2002, DJ 07-05-2004 PP-00036 EMENT VOL-02150-03 PP-00368). Disponível em: <http://redir.stf.jus.br/paginadorpub/paginador.jsp?docTP=AC\&docID=235847>. Acesso em 6 fev. de 2020.
}

Revista de Direito Brasileira | Florianópolis, SC | v. 24 | n. 9 | p.444-462 | Set./Dez. 2019 
Gilmar Ferreira Mendes ${ }^{17}$ defende a dupla função do Recurso Extraordinário, subjetiva e objetiva, principalmente após a promulgação da Lei $\mathrm{n}^{\circ}$. 10.259/2001, que disciplinou a regra recursal perante os Juizados Especiais Federais.

Não há dúvida de que já houve avanços na concepção vetusta que tem caracterizado o recurso extraordinário no âmbito dos juizados especiais federais, deu ao recurso extraordinário características de defesa da ordem constitucional objetiva. Trata-se, na verdade, de orientação que os modernos sistemas de Corte Constitucional vêm conferindo ao recurso de amparo e ao recurso constitucional (Verfassungsbeschwerde). Nesse sentido, destaca-se a observação de Häberle segundo o qual "a função da Constituição na proteção dos direitos individuais (subjectivos) é apenas uma faceta do recurso de amparo", dotado de uma "dupla função", subjetiva e objetiva, "consistindo esta última em assegurar o Direito Constitucional objetivo".

Desta feita, apesar das decisões do Supremo em sede de controle incidental de constitucionalidade não apresentarem a mesma força vinculativa das ações de índole objetiva, tornam-se, indubitavelmente, em normas de conduta, servindo como guia para atuação do jurisdicionado.

De acordo com Sacha Calmon Navarro Coêlho ${ }^{18}$, uma jurisprudência consolidada advinda do Supremo Tribunal Federal ou de outro Tribunal Superior, inclusive aquela que altera entendimento anteriormente consolidada, transforma-se em verdadeira norma judicial.

Assim, uma jurisprudência consolidada, fixa ou precedente, firmada pelo Supremo Tribunal Federal ou outro Tribunal Superior será qualquer decisão, tomada em caráter definitivo pelo Plenário (ou órgão equivalente), que tenha dado resposta a uma questão jurídica geral, verdadeira norma judicial, sendo irrelevante o número de decisões iguais, se única decisão ou se são repetidas, em série. Como resultado, se a uma pergunta geral (que se estende a vários conflitos individuais) é encontrada uma nova resposta, diferente daquela dada pela jurisprudência anterior, teremos uma alteração, uma reviravolta jurisprudencial. Não é necessário que a 'revogação' do entendimento anterior seja expressa, pode ser implícita. Portanto, é a resposta geral (a uma pergunta ou questão) que caracteriza a jurisprudência. Se ela se modifica, então, teremos uma jurisprudência nova. Não importa que denominemos essa resposta geral, de regra judicial, norma concreta, diretriz ou ratio decidendi.

A atual composição do Supremo Tribunal Federal tem-se valido em diversos julgamentos do que batizaram de "princípio da colegialidade", quando, mesmo que um ministro tenha opinião divergente dos demais magistrados em um julgamento, opta por acompanhar as decisões proferidas pelo Plenário em decisão anterior, por respeito à sobredita colegialidade ou vontade dominante naquela ocasião.

EMENTA: "HABEAS CORPUS" - PRESUNÇÃO CONSTITUCIONAL DE INOCÊNCIA (CF, art. $5^{\circ}$, LVII) - DECISÃO EMANADA DE TRIBUNAL DE SEGUNDO GRAU IMPUGNADA EM SEDE DE RECURSOS EXCEPCIONAIS (REsp E RE) - EXECUÇÃO "PROVISÓRIA" DA CONDENAÇÃO PENAL - POSSIBILIDADE - PRECEDENTES DO STF POSIÇÃO DO RELATOR DESTE PROCESSO (MINISTRO CELSO DE

\footnotetext{
${ }^{17}$ MENDES, 2018, p. 1.263.

${ }^{18}$ XAVIER, Alberto [et al.]; coordenador Sacha Calmon Navarro Coêlho. Segurança jurídica: irretroatividade das decisões judiciais prejudiciais aos contribuintes. Rio de Janeiro: Forense, 2013, p. 28.
} 
MELLO), NO ENTANTO, CONTRÁRIA A ESSA ORIENTAÇÃO, POR ENTENDER, EM VOTO VENCIDO, QUE O DIREITO FUNDAMENTAL DE SER PRESUMIDO INOCENTE, QUE NÃO SE ESVAZIA, PROGRESSIVAMENTE, À MEDIDA EM QUE SE SUCEDEM OS GRAUS DE JURISDIÇÃO, PREVALECE ATÉ O TRÂNSITO EM JULGADO DA SENTENÇA PENAL CONDENATÓRIA, COMO DETERMINA A CONSTITUIÇÃO DA REPÚBLICA (ART. 5, LVII) E PRESCREVE, EM CARÁTER IMPERATIVO, O ORDENAMENTO POSITIVO BRASILEIRO (CP, ART. 50; LEP, ARTS. 105 E 147; CPPM, ARTS. 592, 594 E 604) POSIÇÃO MINORITÁRIA, SOBRE A QUAL DEVE PREPONDERAR, NA RESOLUÇÃO DO LITÍGIO, O PRINCÍPIO DA COLEGIALIDADE, RESSALVADO, EXPRESSAMENTE, O ENTENDIMENTO PESSOAL DO RELATOR DESTA CAUSA - "HABEAS CORPUS" INDEFERIDO RECURSO DE AGRAVO IMPROVIDO.

(HC 135933 AgR, Relator(a): Min. CELSO DE MELLO, Segunda Turma, julgado em 22/11/2016, PROCESSO ELETRÔNICO DJe-120 DIVULG 07-062017 PUBLIC 08-06-2017) ${ }^{19}$

Trazendo a interpretação destacada para o objeto deste estudo, se o gestor público age em situação similar àquela definida pelo Supremo Tribunal Federal, cuja decisão, mesmo ocorrendo em ação de índole subjetiva, por prudência deverá guiar sua atuação presente e futura nos moldes definidos naquela decisão.

Portanto, é clara a possibilidade de utilização das decisões paradigmáticas que literalmente reconstruíram o tipo penal previsto no artigo 89 da Lei de Licitações, para fins de subsidiar a propositura de ação de revisão criminal para fins de rescindir eventual condenação pelo crime em tela, quando não preenchidas as novas elementares incluídas pelo Poder Judiciário em repetidas decisões.

No julgamento da Ação Direta de Inconstitucionalidade no 2.240/BA, ficou consignado no voto condutor do Ministro Gilmar Mendes que, se a decisão visa garantir direito fundamental, inclusive ela deverá necessariamente retroagir.

Ficaram as ressalvas, feitas no voto-condutor do Min. GILMAR MENDES de que a teoria da nulidade deve ser prestigiada quando se mostra adequada, inadiável, para proteger direitos fundamentais, com vedações fortes e proibições de violação. Ou seja, se o propósito da própria decisão é garantir um direito fundamental (liberdade, direito de propriedade, dignidade da pessoa, etc.), a retroatividade deverá ser necessariamente adotada. ${ }^{20}$

Mesmo sendo negado por parte da doutrina a extensão erga omnes dos efeitos das decisões da Suprema Corte em declarações incidentais de constitucionalidade ou o reverso, certamente, em sede de matéria criminal, surge fortíssimo argumento para sustentar a propositura da ação de revisão criminal diante da reconstrução do tipo penal em estudo promovida pelo Poder Judiciário.

Sacha Calmon Navarro Coêlho ${ }^{21}$ discorre sobre os efeitos da decisão judicial que cria uma expectativa normativa de comportamento:

[...] Ponderamos que a decisão judicial, no momento em que se firma em uma das alternativas possíveis de sentido (a melhor) dos enunciados legislativos (inclusive

19 BRASIL. Supremo Tribunal Federal. Habeas Corpus 135933. Disponível em: < https://www.jusbrasil.com.br/processos/121395941/processo-n-135933-do-stf>. Acesso em: 7 fev. de 2020.

${ }^{20}$ BRASIL. Supremo Tribunal Federal. ADIN no 2.240/BA, Rel. Min. Eros Grau, Brasília, DF, 2.ago.2007. Disponível em: < http://www.stf.jus.br/imprensa/pdf/adi2240.pdf>. Acesso em 9 fev. de 2020.

${ }^{21}$ XAVIER, 2013, p. 23-24.

Revista de Direito Brasileira | Florianópolis, SC | v. 24 | n. 9 | p.444-462 | Set./Dez. 2019 
da Constituição), criando a norma específica e determinada do caso, e repetível para o mesmo grupo de casos, norma cabível dentro da norma legal, ela fecha as demais alternativas - antes possíveis. As demais alternativas não estarão mais disponíveis, sustentamos, exatamente porque foram afastadas pelo Poder Judiciário, em entendimento consolidado. Desde o momento em que tal fechamento ocorra, o espaço, discricionariamente deixado pelo legislador e possibilitado por uma cadeia de signos e significados inúmeros, concretiza-se e fixa-se em certo sentido único, criando-se verdadeira expectativa normativa de comportamento para todos, integrantes do mesmo grupo de casos. A norma judicial seleciona o significado adequado, o melhor para o caso ou grupo de casos. O fenômeno somente demonstra a correção da posição de HEIDEGGER sobre o alcançar iluminador do âmbito do tempo autêntico, quadridimensional (ou mesmo em quinta dimensão, como quer NORBERT ELIAS), em que a sentença, como acontecimento apropriador (concluímos nós) 'se desapropria, no sentido mencionado, de si mesmo... mas guarda sua propriedade'.

\section{Conforme defende Jean Colbert Dias ${ }^{22}$ :}

É importante frisar que as decisões proferidas pelo Supremo Tribunal Federal produzem padrões de comportamento aos jurisdicionados, também modulam a conduta do gestor público na condução do ato administrativo, sendo crível que após tomar o conhecimento da sobredita decisão, passe a comportar-se pelos seus ditames.

Neste norte, eventuais condenações criminais estribadas na letra fria da norma estudada, ou seja, que tenha criminalizado a conduta de gestores público unicamente por realizar dispensa ou inexigibilidade de licitação fora dos casos previstos em lei ou que tenha desatendido as formalidades de tais procedimentos, mostram-se passíveis de revisão criminal quando ausente na sentença condenatória a demonstração indene do elemento subjetivo especial do tipo agregado à comprovação de dano ao erário público.

Conclui-se, portanto, que o crime meramente formal idealizado pelo legislador passou a ser, por força de repetitivas decisões judiciais, reconstruído sob as bases conceituais de um crime material, que exige a comprovação do seu resultado naturalístico, cujo produto final do delito tenha sido produzido mediante o agir doloso com o fim especial de burlar o procedimento licitatório ou frustrar suas formalidades.

\section{CONSIDERAÇÕES FINAIS}

Ficou evidenciado nesta pesquisa que o artigo 89 da Lei de Licitações passou por franca reconstrução capitaneada pelo Poder Judiciário, tendo consolidado forte escólio jurisprudencial que agrega à norma penal elementares não idealizadas pelo legislador.

A jurisprudência estudada fortificou a premissa que o crime objeto desse estudo urge da comprovação que tenha sido praticado de forma dolosa, com o especial fim de frustrar o procedimento licitatório fora dos casos previstos em lei ou desatender as formalidades essências do ato, agregando à necessidade de demonstração da ocorrência do resultado naturalístico consistente no prejuízo ao erário público.

Ficou evidente, portanto, a (des) construção do tipo penal previsto no artigo 89 da Lei $n^{\circ}$. $8.666 / 93$ pela jurisprudência, que pode impactar claramente em sentenças criminais transitadas em julgado, que cotejaram o tipo penal em apreço sob o viés simplista do mero crime formal.

\footnotetext{
${ }^{22}$ DIAS, Jean Colbert. Responsabilidade do Gestor Público e do Advogado nas Contratações Públicas. Curitiba:
} Juruá, 2019, p. 165.

Revista de Direito Brasileira | Florianópolis, SC | v. 24 | n. 9 | p.444-462 | Set./Dez. 2019 
O estudo contemplou também as decisões das Cortes Superiores, em especial do Supremo Tribunal Federal, cotejando sua força vinculativa e a possibilidade da relativização da coisa julgada criminal.

Por fim, chegou-se à conclusão que os novos paradigmas jurisprudenciais poderão ser utilizados para viabilizar a propositura de ação de revisão criminal para desconstituir condenações penais transitadas em julgado, que não tenham aclarado que o agente público tenha agido de forma dolosa, com a finalidade específica de burlar o procedimento licitatório, agregado à falta de comprovação de que, no caso concreto, tenha havido dano ao erário público.

\section{REFERENCIAS}

BRASIL. Constituição Federal. Disponível em: <http://www.planalto.gov.br/ccivil_03/constituicao/constituicao.htm>. Acesso em: 8 fev. de 2020.

BRASIL. Decreto-Lei no. 2.848, de 07 de dezembro de 1940. Código Penal Disponível em: <http://www.planalto.gov.br/ccivil_03/decreto-lei/del2848compilado.htm>. Acesso em: 6 de fev. de 2020.

BRASIL. Decreto- Lei no . 3.689, de 3 de outubro de 1941. Código de Processo Penal. Disponível em: < http://www.planalto.gov.br/ccivil_03/decreto-lei/del3689compilado.htm >. Acesso em: 11 fev. de 2020.

BRASIL. Supremo Tribunal Federal. ADIN no 2.240/BA, Rel. Min. Eros Grau, Brasília, DF, 2.ago.2007. Disponível em: < http://www.stf.jus.br/imprensa/pdf/adi2240.pdf>. Acesso em 9 fev. de 2020.

BRASIL. Supremo Tribunal Federal. Habeas Corpus $\mathrm{n}^{\circ}$. 135933. Disponível em: < https://www.jusbrasil.com.br/processos/121395941/processo-n-135933-do-stf >. Acesso em: 7 fev. de 2020.

BRASIL. Supremo Tribunal Federal. RE no. 353.657, rel. Min. Marco Aurélio, DJE 25/06/2007, Informativo STF $\mathrm{n}^{\mathrm{o}}$ 463, 16 a 20/04/2007. Disponível em: < http://redir.stf.jus.br/paginadorpub/paginador.jsp?docTP=TP\&docID=7303880>. Acesso em 9 fev. de 2020.

BRASIL. Supremo Tribunal Federal. RE nº 197917, Rel. Min. MAURÍCIO CORRÊA, Tribunal Pleno, julgado em 06/06/2002, DJ 07-05-2004 PP-00036 EMENT VOL-02150-03 PP00368)Disponível em: <http://redir.stf.jus.br/paginadorpub/paginador.jsp?docTP=AC\&docID=235847>. Acesso em 6 fev. de 2020.

BITENCOURT, Cezar Roberto. Direito Penal das Licitações. 1 ed. São Paulo: Saraiva, 2012.

CITADINI, Antônio Roque. Comentários e Jurisprudência sobre a Lei de Licitações e Contratações Públicas. 2 ed. São Paulo: Max Limond, 1997.

CRETELLA JUNIOR, José. Licitações e contratos públicos. 18. ed., Rio de Janeiro: Forense, 2006. 
DIAS, Jean Colbert. Responsabilidade do Gestor Público e do Advogado nas Contratações Públicas: O dolo e a má-fé na responsabilização do advogado e do gestor público. Curitiba: Juruá, 2019.

FREITAS, André Guilherme Tavares de. Crimes na Lei de Licitações. Rio de Janeiro: Lumen Juris, 2007.

GRECO FILHO, Vicente. Dos crimes da Lei de Licitações. 2. ed., São Paulo: Saraiva, 2007.

JUSTEN FILHO, Marçal. Comentários à Lei de Licitações e Contratos Administrativos. 14 ed. São Paulo: Dialética, 2010.

LEONARDO, Marcelo. Crimes de responsabilidade fiscal: crimes contra as finanças públicas; crimes nas licitações; crimes de responsabilidade de prefeitos. Belo Horizonte: Del Rey, 2001.

MENDES, Gilmar Ferreira. Curso de Direito Constitucional. 13 ed. São Paulo: Saraiva Educação, 2018.

SILVEIRA, Vladmir Oliveira da; SANCHES, Samyra Haydêe Dal Farra Naspolini. Direitos humanos, empresa e desenvolvimento sustentável. Revista Jurídica, [S.1.], v. 1, n. 38, p. 313327, dez. 2015. ISSN 2316-753X. Disponível em: <http://revista.unicuritiba.edu.br/index.php/RevJur/article/view/1422>. Acesso em: 08 abr. 2019.

STOCCO, Rui. Leis penais e sua interpretação jurisprudencial. 7. ed., São Paulo: Revista dos Tribunais, 2001, v. 3.

STRECK, Lenio Luiz. Jurisdição Constitucional e Hermenêutica: uma nova crítica do Direito. Porto Alegre: Livraria do Advogado, 2002.

XAVIER, Alberto [et al.]; coordenador Sacha Calmon Navarro Coêlho. Segurança jurídica: irretroatividade das decisões judiciais prejudiciais aos contribuintes. Rio de Janeiro: Forense, 2013, p. 28. 